\title{
Experimental Model for Cu(II) and Fe(III) Sorption from Synthetic Solutions Based on Maize Stalk
}

\author{
NICOLETA MIRELA MARIN ${ }^{*}$, GHEORGHE BATRINESCU ${ }^{1}$, IOANA STANCULESCU ${ }^{2,3}$, \\ LUCIAN CONSTANTIN ${ }^{1}$, NICOLAE IONUT CRISTEA ${ }^{1}$, ALEXANDRA IOANA IONESCU ${ }^{1}$, \\ GINA ALINA TRAISTARU ${ }^{1}$ \\ ${ }^{1}$ National Research and Development Institute for Industrial Ecology ECOIND, 71-73 Podu Dambovitei, 060652, \\ Bucharest, Romania \\ ${ }^{2}$ University of Bucharest, Faculty of Chemistry, Department of Physical Chemistry, 4-12 Regina Elisabeta Blvd., 030018, \\ Bucharest, Romania \\ ${ }^{3}$ Horia Hulubei National Institute for Physics and Nuclear Engineering, Centre of Technological Irradiations IRASM, 30 \\ Reactorului Str., 077125, Magurele, Romania
}

\begin{abstract}
This study is based to a new concept, to use maize stalk for specific sorption and recovery of $\mathrm{Cu}(\mathrm{II})$ and $\mathrm{Fe}(\mathrm{III})$ from synthetic solutions. Thus, the sorption properties of the biomass resulting from the recycling of the maize stalk that reached maturity (autumn) were studied. In the first stage, the sorption properties of the maize stalk were evaluated in batch system. Moreover, in terms of water quality improvement several key parameters that influence the sorption equilibrium were evaluated. The effect of contact time (0-120min) and cations initial concentration (investigated range: 0.05-0.4 $\mathrm{mg} / \mathrm{L}$ ) on biomaterial sorption capacity were assessed. Kinetic studies were performed taking into consideration the initial concentration of metallic cation. The experimental data were analyzed based on first order kinetic model, pseudo-second-kinetic model and Morris Webber kinetic model. The kinetics of sorption was in accordance with the pseudo - second - kinetic model as the correlation coefficients showed $\left(R^{2}=0.9940\right.$ for $\mathrm{Cu}(\mathrm{II})$ and $R^{2}=0.9999$ for $\left.\mathrm{Fe}(\mathrm{III})\right)$. Moreover the desorption study was evaluated with hydrochloric acid and have detected to be $63 \%$ and $89 \%$ for $\mathrm{Cu}$ (II) and Fe(III) when $4 \mathrm{M} \mathrm{HCl}$ is used. The surface of the maize stalk loaded with $\mathrm{Cu}(\mathrm{II})$ and $\mathrm{Fe}(\mathrm{III})$ was characterized by various specific techniques such as FTIR-ATR, SEM, and TG. Experimental results revealed that cations sorption process takes place on the sorbent surface. The sorption rate of each metallic cation is controlled by the formation of chemical bonds with surface polar groups. Their presence on biomass structure, evidenced by FTIR-ATR analysis, explains the behavior of maize stalk as a weak ion exchanger acid.
\end{abstract}

Keywords: maize stalk, sorption kinetic modes, experimental model, copper(II), iron(III)

\section{Introduction}

Nowadays the pollution of the environment with dangerous metals is one of the major problems worldwide $[1,2]$. At the same time, considerable quantities of waste water generated by anthropogenic activities such as mining and other industries can induce a major alteration of ecosystems and severe human health problems [3]. The mine activities can generate an environmental pollution with valuable metals such as gold, silver, copper, iron, zinc and others [4-6]. In order to reduce the pollution, a variety of technologies has been intensively applied for the removal of metals from wastewater. Moreover, an ecological technology with multiple benefits, that do not require laborious processing, can encourage to use vegetable or mineral waste as an alternative to conventional technologies [7]. Currently, at gloal levels, vegetable wastes are available in large quantities following the processing of agricultural crops. Vegetable wastes contain cellulose, hemicellulose, lignin and many other compounds such as lipids, starch, hydrocarbons and simple proteins. Cellulose is a linear polymer composed of $\beta$-glucose molecules and is found in the composition of plants together with hemicellulose and lignin. These substances make up the walls of plant cells providing mechanical strength and elasticity.

\footnotetext{
*email: nicoleta.marin@incdecoind.ro
} 
The hydroxyl groups from polymer chain structure of those vegetable wastes can ionize in aqueous medium and act as a weak acid cation exchanger. One of the most growed cereals in many regions of the world is maize stalk, representing $80 \%$ of cereal production along with wheat. Taking into account the abundance of maize stalk and the properties of weak cation exchanger, recent researches evaluated the feasibility of using the maize stalk for the removal of some metals from synthetic solutions and from wastewater. Zheng L. et al., used cellulose isolated from corn stalk, which was modified by copolymerization with $\mathrm{N}, \mathrm{N}^{\prime}$-bis-methyl(acrylamide) to retain $\mathrm{Cd}(\mathrm{II})$ in aqueous solutions. The experimental data were best correlated by applying the Langmuir isotherm and the maximum sorption capacity was $21.37 \mathrm{mg} / \mathrm{g}$ for the modified cellulose [8]. Majid R. et al., presented the experiments in which the corn cobs were used for the retention of $\mathrm{Zn}(\mathrm{II}), \mathrm{Cr}(\mathrm{III})$ and $\mathrm{Ni}(\mathrm{II})$. Sorption studies revealed that corn cobs had a significant efficiency in retaining heavy metal cations: $\mathrm{Cr}$ (III) was removed up to 95.05\%, (at $p \mathrm{H}-4.5$ in $4.18 \mathrm{~h}$ ), a good sorption capacity was observed for $\mathrm{Ni}(\mathrm{II})$ at $p \mathrm{H}-6.5$ in $0.15 \mathrm{~h}$, while a lower yield retention was obtained for $\mathrm{Zn}$ (II) $91.35 \%$ in the same conditions [9]. Muthusamy P. et al., studied the retention of $\mathrm{Ni}$ (II) on activated maize cob. The studied parameters were: the contact time, the optimum amount of biomaterial and the stirring speed. Freundlich isotherm was used to describe the sorption equilibrium. Following the experimental study it was shown that maize cob, a residual material, can be used for the retention of $\mathrm{Ni}$ (II) in industrial waters [10]. The adsorption of Mn(II) from aqueous solutions on activated maize strain was studied by Fariba N. et al. The batch method was used to test the effect of $p \mathrm{H}$, initial concentration, contact time and temperature on the sorption capacity of the activated maize strain. The authors showed that the increase of $\mathrm{Mn}$ (II) initial concentration led to decrease of its retention capacity on the biomaterial surface (at $p \mathrm{H}-5$, after $65 \mathrm{~min}$ of stirring). The Freundlich model $\left(\mathrm{R}^{2}=0.9943\right)$ describes the sorption process better than the Langmuir model $\left(\mathrm{R}^{2}=0.9717\right)$, indicating a sorption on heterogeneous surfaces. Thermodynamic data showed that the sorption process was exothermic and spontaneous [11]. Moreover, in literature are presented some other plant materials for removal metallic cation (Table 1).

Table 1. Sorption capacity of biomaterials obtained from barley and wheat straw for removal of metallic cations from water/waste water

\begin{tabular}{cccc}
\hline $\begin{array}{c}\text { Material } \\
\text { celulozic }\end{array}$ & $\begin{array}{c}\text { Metallic } \\
\text { cation }\end{array}$ & $\begin{array}{c}\text { Sorption } \\
\text { capacity (mg/g) }\end{array}$ & $\begin{array}{c}\text { Reference } \\
\text { s }\end{array}$ \\
\hline Wheat straw & $\mathrm{Cd}(\mathrm{II})$ & 14.6 & {$[12]$} \\
\hline Wheat straw & $\mathrm{Cu}(\mathrm{II})$ & 11.4 & {$[12]$} \\
\hline Salvinia biomass & $\mathrm{Cr}(\mathrm{VI})$ & 47.2 & {$[13]$} \\
\hline Salvinia biomass & $\mathrm{Ni}(\mathrm{II})$ & 41.8 & {$[13]$} \\
\hline Breath wheat & $\mathrm{Cd}(\mathrm{II})$ & 39.2 & {$[14]$} \\
\hline Wheat bran & $\mathrm{Pb}(\mathrm{II})$ & 62.0 & {$[15]$} \\
\hline Barley straw & $\mathrm{Cu}(\mathrm{II})$ & 4.64 & {$[16]$} \\
\hline Barley straw & $\mathrm{Pb}(\mathrm{II})$ & 23.2 & {$[16]$} \\
\hline
\end{tabular}

However an experimental model that uses maize stalk for $\mathrm{Cu}$ (II) and $\mathrm{Fe}$ (III) removal from synthetic solution , up to our knowledge, can not be found within the literature.

\section{Materials and methods}

\subsection{Acid treatment of maize stalk}

The sieved maize stalk was inserted into glass column with inside diameter of $3 \mathrm{~cm}$ and $25 \mathrm{~cm}$ length. An acid treatment (using 4M HCl solution) was applied. After this treatment, the maize stalk was washed until excess acid was removed. Subsequently, the maize stalk was removed from the column, dried at laboratory temperature for $48 \mathrm{~h}$ and used in sorption studies.

\subsection{Reagents}

In our experiments $\mathrm{HCl} 37 \%$ (density $1.16 \mathrm{~g} / \mathrm{mL}$ ) purchased from Merck, without traces of metallic cations was used for activated maize stalk and for desorption studies. Ultra-clear water $(18 \mathrm{M} \Omega \cdot \mathrm{cm})$ 
was produced by Ultra Clear system (Evoqua Water Technologies) and was used to prepare synthetic solutions, dilutions and washing glassware and maize stalk matrix. MRC solutions (certified reference materials) were purchased from Merck with concentration of $1000 \mathrm{mg} / \mathrm{L}\left(\mathrm{Fe}\left(\mathrm{NO}_{3}\right)_{3}\right.$ and $\mathrm{Cu}\left(\mathrm{NO}_{3}\right)_{2}$ in $\mathrm{HNO}_{3} 0.5 \mathrm{~mol} / \mathrm{L}$ ) were used for the calibration curves as well as for evaluating the sorption capacity of the maize stalk on synthetic solutions and environmental samples.

\subsection{Methodology for sorption experiments (metallic cation-maize stalk) in synthetic solution}

All sorption experiments were performed using batch method. For this purpose, an amount of $0.1 \mathrm{~g}$ of activated biomaterial was stirred for 1 hour, at a speed of $175 \mathrm{rpm}$, at laboratory temperature, with 0.02L solutions of metallic cations with different concentrations. At the end of the experiment, the samples were filtered on Wathman filter paper and the supernatant was collected in volumetric flasks. The concentration of the metallic cations in solution was determined using the ICP-MS.

\subsection{Methodology for desorption study}

For desorption study, the batch procedure was applied to verify the recovery of the metallic cations retained on the biomaterial. For this purpose $0.1 \mathrm{~g}$ biomaterial samples loaded with metallic cations were stirred with $0,025 \mathrm{~L}$ of $\mathrm{HCl}$ with various concentrations $(1,2,3$ and $4 \mathrm{M})$. The samples investigated in this study were stirred for $30 \mathrm{~min}$ at $175 \mathrm{rpm}$. The supernatant obtained was filtered and analyzed using the ICP-MS Aurora M90 Bruker (Inductive coupled plasma-mass spectrometry), to determinated metallic cations concentration.

\subsection{Material characterization}

In order to detect organic groups involved in retention of the metallic cations the ATR-FTIR (Attenuated total reflection infrared spectroscopy) analysis were performed with a Bruker Vertex 70 FTIR spectrometer equipped with ATR accessory and diamond crystal. The infrared spectra of solid samples were recorded in range $4000-600 \mathrm{~cm}^{-1}$ with $128 \mathrm{scans}$ at $4 \mathrm{~cm}^{-1}$ spectral resolution.

A Quanta FEG 250 scanning electronic microscope was used to record all images of the solid samples of maize stalk studied before and after contact with synthetic solution. The working mode regarding the vacuum level was realized in the water vapor atmosphere specific for the porous materials. For this purpose the extended field detector (LF) was used in vacuum mode.

\subsection{Calculation of $\mathrm{Cu}(\mathrm{II})$ and $\mathrm{Fe}(\mathrm{III})$ sorption}

The quantity of each metallic cation removed from synthetic solution $\left(\mathrm{Q}_{\mathrm{e}}\right)$ was evaluated using the following equation:

$$
Q_{e}=\frac{\left(C_{o}-C_{e}\right) V}{m}(\mathrm{mg} / \mathrm{g})
$$

Percents of $\mathrm{Cu}(\mathrm{II})$ and $\mathrm{Fe}(\mathrm{III})$ removed from synthetic solution were calculated by the following ecuation:

$$
(\%)=\frac{\left(C_{o}-C_{e}\right)}{C_{o}} \times 100 \%
$$

The amount of metallic cations removed at time $\mathrm{t}(Q t)$, was calculated by the next equation:

$$
Q_{t}=\frac{\left(C_{o}-C_{t}\right) V}{m}(\mathrm{mg} / \mathrm{g})
$$

where $C_{o}, C_{e}$ and $C_{t}$ represent the concentrations of metallic cations, in solution, initially, at equilibrium and at the time $\mathrm{t}$, respectively. Moreover $\mathrm{m}(\mathrm{g})$ is the mass of biomaterial applied in experiment and $\mathrm{V}$ is the volume of the sample $(\mathrm{L})$.

\section{Results and discussions}

\subsection{Study of the contact time influence}

The time required to reach equilibrium was studied in the range $0-120 \mathrm{~min}$. The state of equilibrium was achieved after 60-120 min where the maximum sorption capacity on the 
biomaterial mass varied insignificantly (Figure 1). Thus, 60 min was selected as optimum contact time for $\mathrm{Cu}(\mathrm{II})$ and $\mathrm{Fe}(\mathrm{III})$ and used to evaluate the properties of the biomaterial in the further experiments.

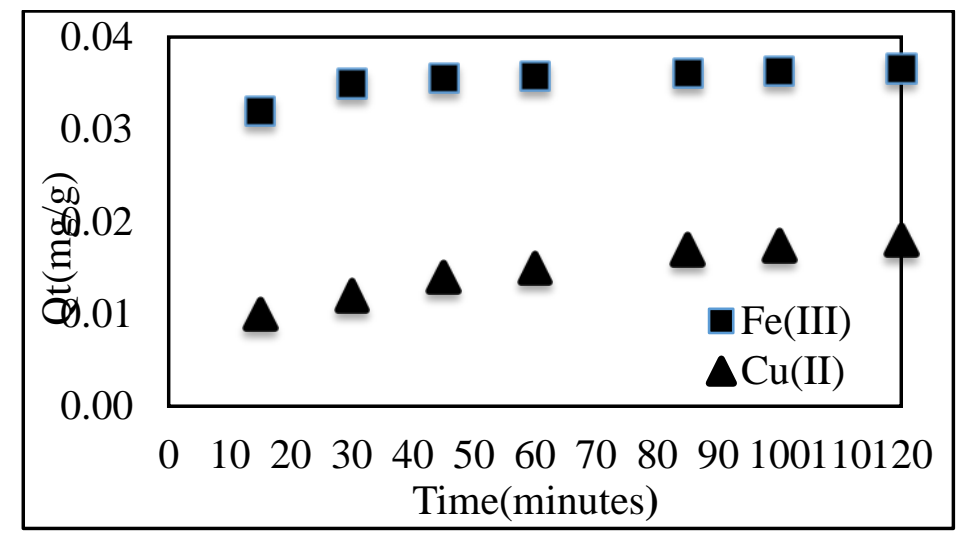

Figure 1. Influence of the contact time on the sorption capacity to the biomaterial, concentration of metallic cation $0.25 \mathrm{mg} / \mathrm{L}, 0.1 \mathrm{~g}$ biomaterial, $175 \mathrm{rpm}$ stirring speed, $1 \mathrm{~mm}$ particle size, $25^{\circ} \mathrm{C}$ and $0.02 \mathrm{~L}$ volume of synthetic solutions

\subsection{The influence of biomaterial particle on the sorption process}

The effect of particle size on $\mathrm{Cu}$ (II) and $\mathrm{Fe}$ (III) sorption in the biomaterial represented by the maize stalk was studied using five different particle diameters namely 2.0, 1.0, 0.25, 0.12 and $0.063 \mathrm{~mm}$. As can be seen in Figure 2 the quantity of removed metallic cation increases with the decrease of biomaterial size particle. Thus the quantity removed from the solution ranged from $0.024 \mathrm{mg} / \mathrm{g}(2 \mathrm{~mm})$ to $0.039 \mathrm{mg} / \mathrm{g}(0.06 \mathrm{~mm})$ for $\mathrm{Fe}(\mathrm{III})$ and for $\mathrm{Cu}$ (II) from $0.013 \mathrm{mg} / \mathrm{g}(2 \mathrm{~mm})$ up to $0.023 \mathrm{mg} / \mathrm{g}(0.063$ $\mathrm{mm})$. The different quantity of metallic cations removed can be explained by the fact that for the particles with smaller diameter, the diffusion is faster inside them and at the exchange centers as a result of the increase to specific surface.

Although particle size decreasing positively influences the sorption capacity of the biomaterial, obtaining of smaller particle size is expensive, thus, evaluation of biomaterial sorption capacity was performed using $1 \mathrm{~mm}$ particle size, in order to decreases treatment costs.

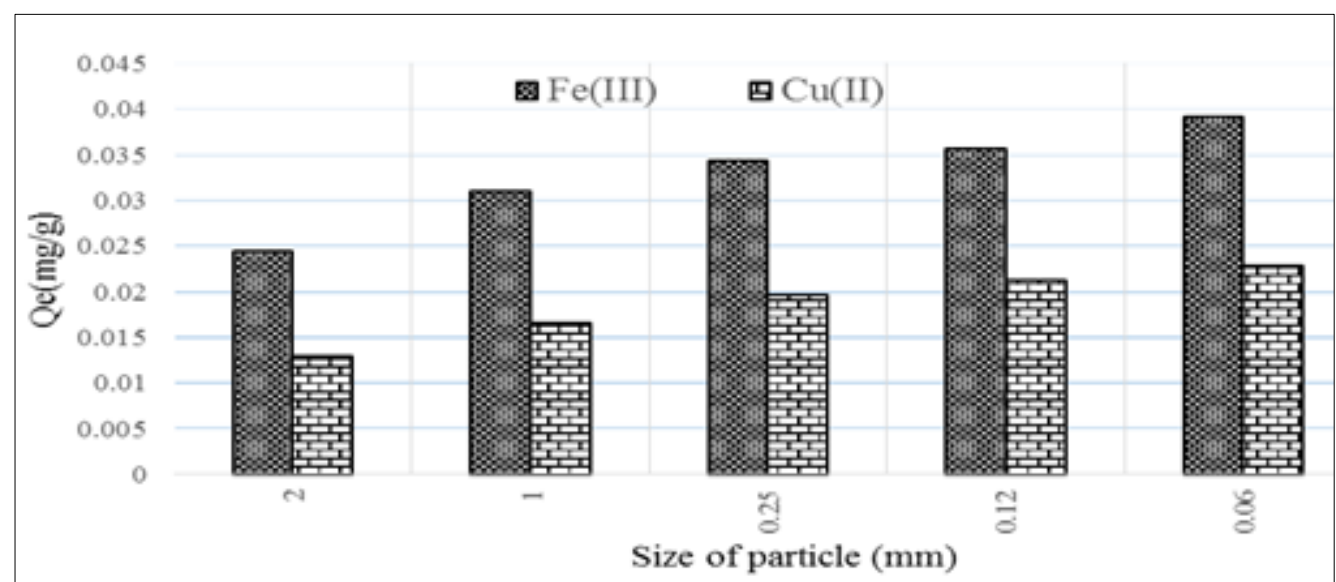

Figure 2. Influence of particle size to biomaterial sorption of $\mathrm{Cu}(\mathrm{II})$ and $\mathrm{Fe}(\mathrm{III})$ from solution with $0.25 \mathrm{mg} / \mathrm{L}$ concentration, $175 \mathrm{rpm}$ stirring speed, $25^{\circ} \mathrm{C}$ and $0.02 \mathrm{~L}$ volume of synthetic solutions for $60 \mathrm{~min}$ 


\subsection{Study of the initial concentration}

To study the influence of pollutant concentration, the amount of biomaterial was kept constant and the initial concentrations were increased [17]. Thus, the variation of the initial concentration induces significantly influences on sorption capacity at equilibrium. The Figure 3 shows the experimental profile of the sorption isotherms for the studied metallic cations. The experimental result of the process beginning showed a fast sorption and then becomes slow with the obtained equilibrium when the maximum capacity of the biomaterial is reached.

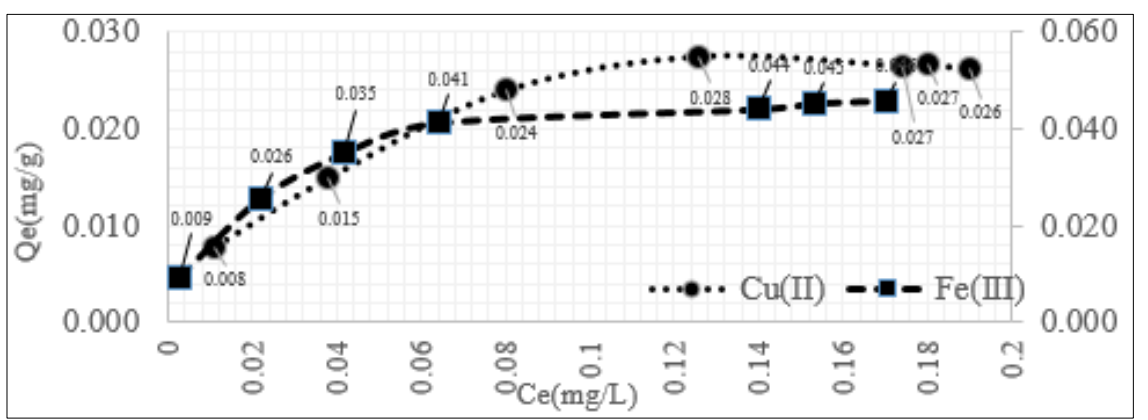

Figure 3. Influence of initial concentration $(0,05-0,4 \mathrm{mg} / \mathrm{L})$ on $\mathrm{Cu}(\mathrm{II})$ and $\mathrm{Fe}(\mathrm{III})$ sorption from solution, $0.1 \mathrm{~g}$ biomaterial, $175 \mathrm{rpm}$ stirring speed, $1 \mathrm{~mm}$ particle size, $25^{\circ} \mathrm{C}, 0.02 \mathrm{~L}$ volume of synthetic solutions and $60 \mathrm{~min}$

\subsection{Isotherm study}

The distribution of metallic cations between the two phases (liquid/solid) is a measure of the equilibrium that can be revealed based on the sorption isotherms. The obtained data were modeled using equations of Langmuir and Freundlich models (Table 2).

Langmuir equation

\section{Freundlich equation}

$$
\frac{\mathrm{C}_{\mathrm{e}}}{\mathrm{Q}_{\mathrm{e}}}=\frac{1}{\mathrm{bQ}_{0}}+\frac{\mathrm{C}_{\mathrm{e}}}{\mathrm{Q}_{0}}
$$

$$
\ln \mathrm{Q}_{\mathrm{e}}=\ln \mathrm{K}_{\mathrm{f}}+\frac{1}{\mathrm{n}} \ln \mathrm{C}_{\mathrm{e}}
$$

Where: $\mathrm{Q}_{0}$ is sorption capacity of the biomaterial, $\mathrm{b}(\mathrm{L} / \mathrm{mg})$ the Langmuir constant which is correlated with the affinity of the biomaterial reported to $\mathrm{Cu}(\mathrm{II})$ and $\mathrm{Fe}(\mathrm{III}), \mathrm{R}^{2}$ correlation coefficient, $\mathrm{R}_{\mathrm{L}}$ partition coefficient (dimensionless parameter), Kf is the Freundlich constant correlated with the sorption ability of biomaterial and $\mathrm{n}$ is a constant correlated with the intensity of the sorption process.

Table 2. Isotherms parameters for $\mathrm{Cu}$ (II) and $\mathrm{Fe}(\mathrm{III})$ sorption in maize stalk activated

\begin{tabular}{ccc}
\hline Isotherm model & $\mathbf{C u}(\mathbf{I I})$ & $\mathbf{F e}(\mathbf{I I I})$ \\
\hline Langmuir & & \\
\hline $\mathrm{Q}_{\mathrm{o}}(\mathrm{mg} / \mathrm{g})$ & 0.032 & 3.02 \\
\hline $\mathrm{b}(\mathrm{L} / \mathrm{mg})$ & 0.03 & 60.2 \\
\hline $\mathrm{R}_{\mathrm{L}}$ & 0.9 & 0.27 \\
\hline $\mathrm{R}^{2}$ & 0.9878 & 0.9982 \\
\hline Freuindlich & & \\
\hline $\mathrm{Kf}(\mathrm{L} / \mathrm{g})$ & 2.81 & 2.28 \\
\hline $1 / \mathrm{n}$ & 0.44 & 0.39 \\
\hline $\mathrm{R}^{2}$ & 0.9454 & 0.9477 \\
\hline
\end{tabular}

Isotherms were evaluated based on linear regression by estimating the correlation coefficients. The linear profile of Langmuir isotherm was obtained by graphical representation of Ce/Qe ratio versus Ce. 
The correlation coefficients calculated were 0.9982 for $\mathrm{Fe}(\mathrm{III})$ and 0.9878 to $\mathrm{Cu}(\mathrm{II})$ as is presented in Figures 4 (a) and (b).
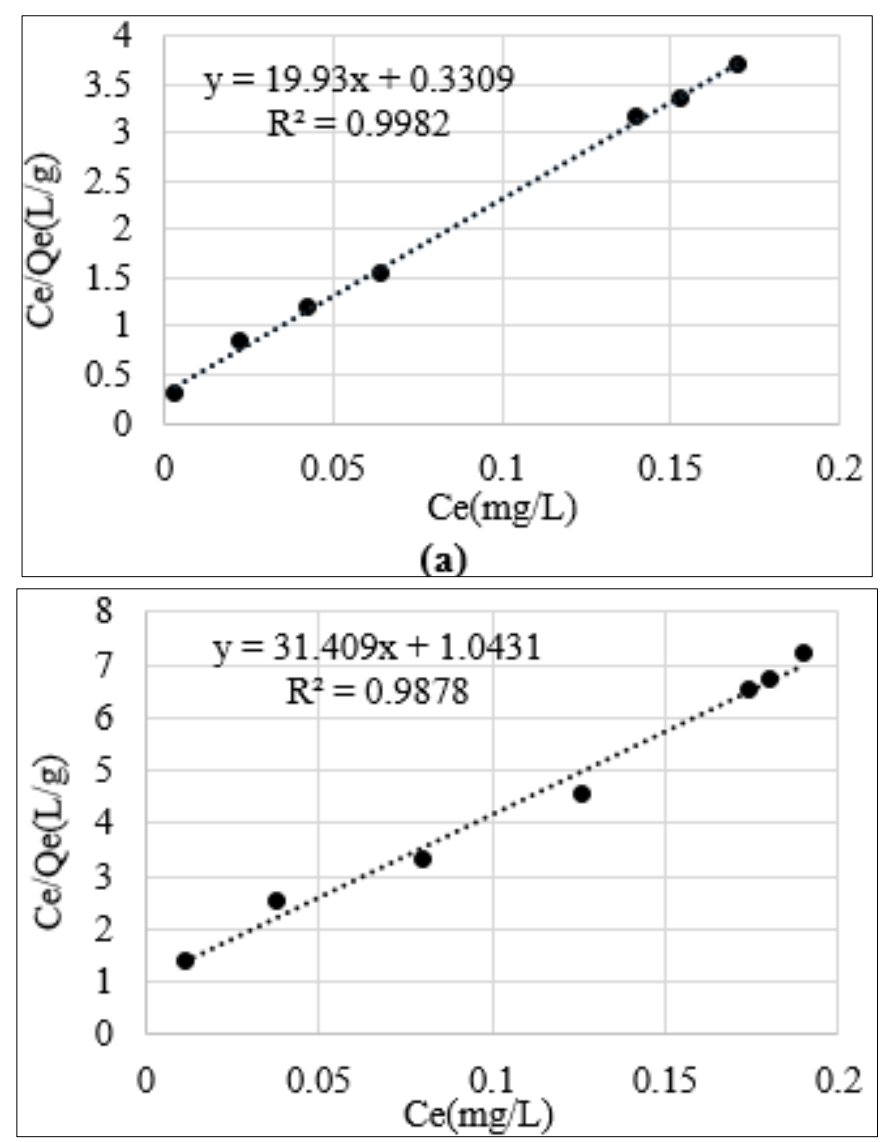

(b)

Figure 4. Linear isotherm modeling for $\mathrm{Fe}(\mathrm{III})(\mathbf{a})$ and (b) to $\mathrm{Cu}$ (II) using Langmuir model

Obtained values of $R_{L}$ parameter, which are situated in the range $0-1$, confirms efficiently sorption of $\mathrm{Cu}(\mathrm{II})$ and $\mathrm{Fe}(\mathrm{III})$ on maize stalk, as showed results presented in Table 2. The applicability of the Freundlich isotherm was evaluated by graphically representation of the lnQe versus lnCe values. Moreover, the values of the correlation coefficients of the Freundlich model were close to Langmuir model results that indicated the sorption can be achieved both on the homogeneous and the nonhomogeneous surface of the biomaterial. Also, the values of $1 / \mathrm{n}$ (Table 2) were lower than 1 revealed that the $\mathrm{Cu}(\mathrm{II})$ and $\mathrm{Fe}(\mathrm{III})$ were efficiently removed.

\subsection{Kinetic study of the sorption process}

The experimental data obtained under the influence of the contact time were processed based on first order kinetic model, pseudo-second-kinetic model and the Morris Webber kinetic model [18-21]. The kinetic data were obtained by modulated the fallowing equation:

First order kinetic model equation

Morris-Weber equation

$$
\log \left(\mathrm{q}_{\mathrm{e}}-\mathrm{q}_{\mathrm{t}}\right)=\log \mathrm{q}_{\mathrm{e}}-\left(\frac{\mathrm{k}_{1}}{2,303}\right) \mathrm{t}
$$

$$
\mathrm{q}_{\mathrm{t}}=\mathrm{k}_{\mathrm{id}}(\mathrm{t})^{0,5}+C
$$

Pseudo-second order equation 


$$
\frac{\mathrm{t}}{\mathrm{q}_{\mathrm{t}}}=\frac{1}{\mathrm{k}_{2}\left(\mathrm{q}_{\mathrm{e}} \mathrm{q}_{\mathrm{e}}\right)}+\frac{\mathrm{t}}{\mathrm{q}_{\mathrm{e}}}
$$

where: qe, qt are the quantity of $\mathrm{Cu}(\mathrm{II})$ and $\mathrm{Fe}(\mathrm{III})$ retained at equilibrium and at time $\mathrm{t}$, respectively, $\mathrm{k}_{1}$ and $\mathrm{k}_{2}\left(\mathrm{~min}^{-1}\right)$ are the rate constants of the sorption process of first order and second order model, respectively. The $\mathrm{C}$ is a dimensionless constant, which represents the amount of metal retained on the surface of the biomaterial and $\mathrm{k}_{\mathrm{id}}\left(\mathrm{min}^{-1}\right)$ is the value of the intra-particle diffusion constant.

The sorption capacities as well as the sorption constants $\mathrm{k}_{1}$ and $\mathrm{k}_{2}$ were calculated from the graphical representations of the $\log (\mathrm{qe}-\mathrm{qt})$ as a function of time and $\mathrm{t} / \mathrm{qt}$ versus $\mathrm{t}$ for the first and second order kinetic model, respectively. The first kinetic model was studied at $0.25 \mathrm{mg} / \mathrm{L}$ concentration value in the time interval $0-120 \mathrm{~min}$, starting from the hypothesis that intra-particle sorption is a limiting rate step. Following the experimental studies in the first 60 min a rapid sorption occurs. This confirms that the kinetic model cannot predict sorption rate of $\mathrm{Cu}$ (II) and $\mathrm{Fe}$ (III) in the mass of biomaterial during the whole stirring interval. The diffusion rate $\mathrm{k}_{\mathrm{id}}\left(\mathrm{min}^{-1}\right)$ was calculated from the slope of the linear equation while the amount of metallic cation removal on the surface of the maize stalk was determined from the intercept of representation $\mathrm{Q}_{\mathrm{e}}$ versus $\mathrm{t}^{0.5}$ (half time). The graphical representation of $\mathrm{Q}_{\mathrm{e}}$ according to $\mathrm{t}^{0.5}$ is a curve that does not pass through the origin. The values of the intercept give us information regarding the thickness of the layer. Moreover, a high value of constant $\mathrm{C}$ indicates the increase of the thickness layer on the outside surface reducing the possibility of internal transfer, aspect observed in the case of $\mathrm{Fe}$ (III) where the value of constant $\mathrm{C}$ approaches the maximum sorption amount of $0.043 \mathrm{mg} / \mathrm{g}$ determined at equilibrium. The experimental data were further processed according to the second order kinetic model. Sorption capacity detected at equilibrium was in accordance with the kinetics value of this model for the whole studied time interval. The results obtained suggest that the sorption mechanism given by the second order kinetic model was predominant and the sorption rate of each metallic cation is controlled by the chemical bonds. The experimental values obtained after fitted all kinetic models are presented in Table 3.

Table 3. The kinetic constants of the studied models based on the tested biomaterial

\begin{tabular}{ccc}
\hline Kinetic model & $\mathbf{C u}(\mathbf{I I})$ & $\mathbf{F e}(\mathbf{I I I})$ \\
\hline Lagergren model & & \\
\hline $\mathrm{k}_{1}\left(\mathrm{~min}^{-1}\right)$ & 0.031 & 0.033 \\
\hline $\mathrm{qe}$ calc. $(\mathrm{mg} / \mathrm{g})$ & 66 & 182 \\
\hline $\mathrm{qe}$ exp.(mg/g) & 0.018 & 0.036 \\
\hline $\mathrm{R}^{2}$ & 0.9781 & 0.9553 \\
\hline Morris-Weber model & & \\
\hline $\mathrm{k}_{\mathrm{id}}\left(\mathrm{min}^{-1}\right)$ & 0.0012 & 0.0006 \\
\hline $\mathrm{C}$ & 0.005 & 0.031 \\
\hline $\mathrm{R}^{2}$ & 0.9921 & 0.7748 \\
\hline Pseudo-secound order model & \\
\hline $\mathrm{k}_{2}(\mathrm{~g} /(\mathrm{mg} \cdot \mathrm{min}))$ & 2.5 & 13 \\
\hline $\mathrm{q}_{\mathrm{e}}(\mathrm{mg} / \mathrm{g})$ & 0.021 & 0.037 \\
\hline $\mathrm{R}^{2}$ & 0.9940 & 0.9999 \\
\hline
\end{tabular}

\subsection{Desorption of metallic cations from the maize stalk}

The desorption of metallic cations from the matrix of maize stalk after reaching equilibrium using various concentrations of $\mathrm{HCl}$, was investigated. As is shown in Figure 4, the stability for $\mathrm{Cu}(\mathrm{II})$ and Fe(III) loaded in maize stalk is weakly affected by the $0.1 \mathrm{M} \mathrm{HCl}$ solution. Nevertheless, the predilection of their removal to the biomaterial is in accordance with the theoretical rules, when the $\mathrm{HCl}$ concentration is higher the percentages removed from the matrix are higher. However, it is also found that $4 \mathrm{M} \mathrm{HCl}$ has the strongest desorption effect for $\mathrm{Cu}(\mathrm{II})$ and $\mathrm{Fe}(\mathrm{III})$ studied from the maize stalk. The results obtained in this case are shown in Figure 5. 


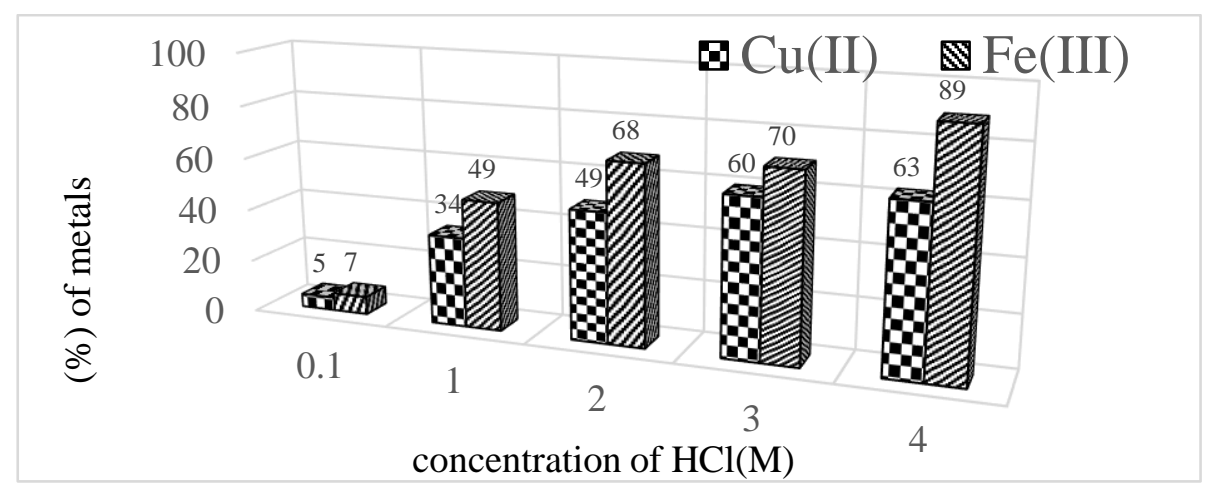

Figure 5. Desorption of the metallic cations from the maize stalk using $\mathrm{HCl}$

\subsection{FTIR-ATR studies}

The ATR spectrum of the maize stalk shows the characteristic signals of the main macromolecular components: cellulose, lignin and hemicellulose [22-26]. Comparing the maize stalk spectra in the pre - and post-sorption phases were observed differences of intensity and position of the bands (only the interior area of the maize stalk was analyzed), as is presented in Figures 6-8. Significant changes in intensity and band displacements occur in the area of the vibrational frequencies - $\mathrm{OH}$ and of the C-O$\mathrm{C}$ characteristic groups of cellulose, the polar groups being responsible for the sorption of the metallic cations.

Table 4. Functional groups pre and post of $\mathrm{Cu}(\mathrm{II})$ and $\mathrm{Fe}(\mathrm{III})$ on maize stalk

\begin{tabular}{llll}
\hline $\begin{array}{l}\text { Functional } \\
\text { groups }\end{array}$ & $\begin{array}{l}\text { Maize stalk } \\
(\mathbf{c m})\end{array}$ & Maize stalk-Fe(III) $\left(\mathbf{c m}^{-\mathbf{1}}\right)$ & $\begin{array}{l}\text { Maize stalk-Cu(II) } \\
\left(\mathbf{c m}^{-\mathbf{1}}\right)\end{array}$ \\
\hline$v \mathbf{O H}$ & 3340.71 & 3343.73 & 3341.98 \\
\hline$v \mathbf{C H}$ & 2899.08 & 2917.68 & 2901.14 \\
\hline$v \mathbf{C = O}$ & 1712.57 & 1731.19 & 1731.27 \\
\hline$v \mathbf{C}=\mathbf{C}$ & 1514.32 & 1514.64 & 1514.94 \\
\hline$v \mathbf{C}-\mathbf{H}$ & 1369.51 & 1371.68 & 1371.83 \\
\hline$v \mathbf{C}-\mathbf{O}$ & 1034.36 & 1036.28 & 1036.87 \\
\hline
\end{tabular}

From the Table 4 and the analysis of Figures 6-8 the results presents the largest displacements of the band for the functional polar groups while the vibration of the nonpolar $\mathrm{C}=\mathrm{C}$ bond of lignin remains almost constant at $1514 \mathrm{~cm}^{-1}$. Consequently, during the sorption process, many of the groups can existing in the maize stalk structure were ionized under certain experimental conditions and can interaction with the studied metallic cations. A possible explanation to this behavior is the fact this biomaterial behaves as a weak ion exchanger acid.

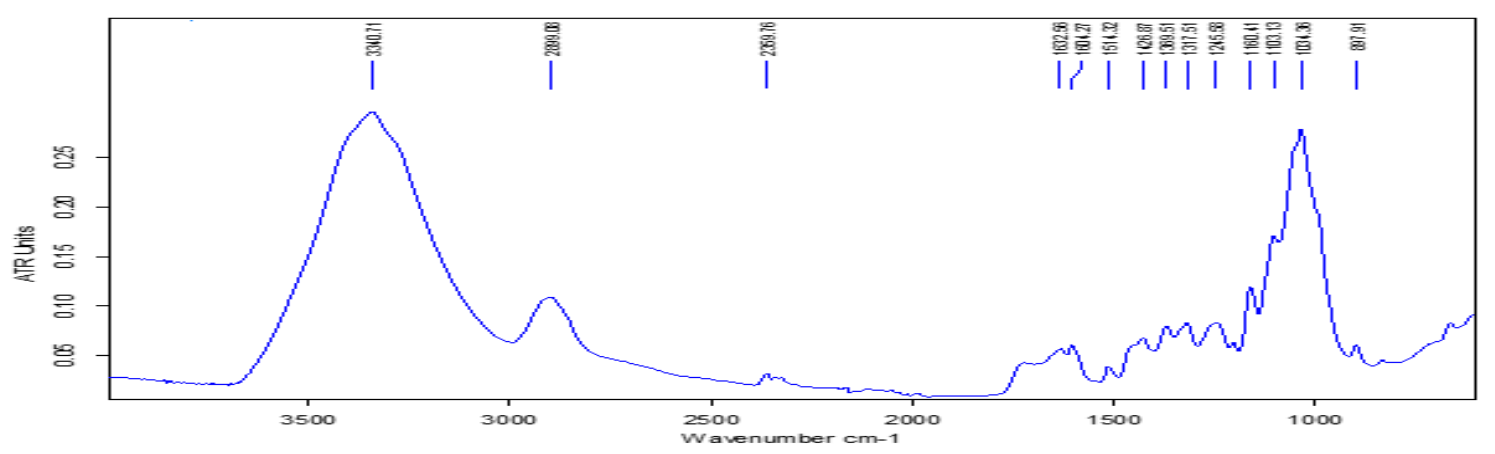

Figure 6. FTIR-ATR spectra of the activated maize stalk 


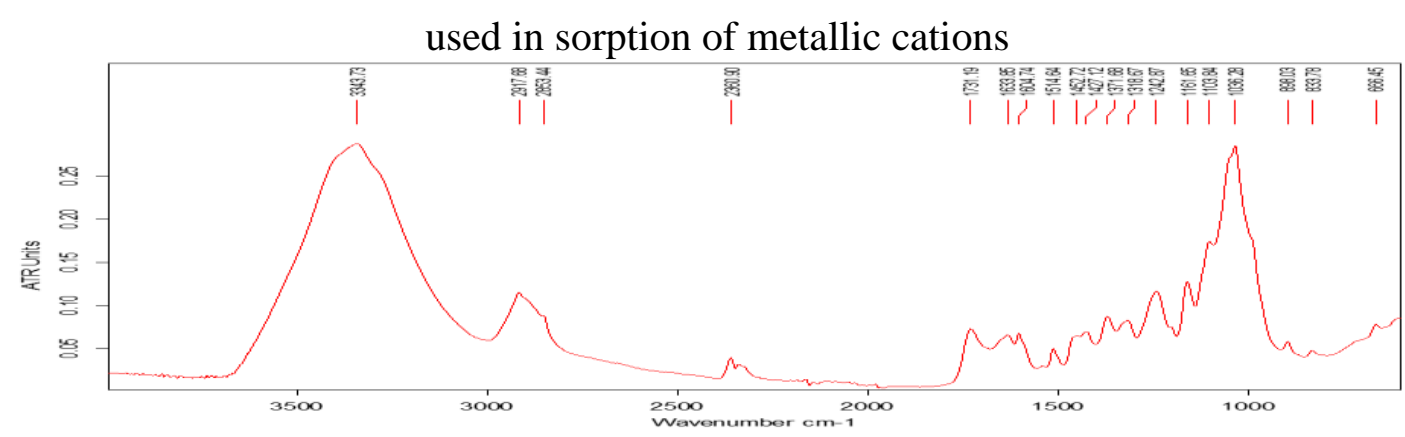

Figure 7. FTIR-ATR spectra of maize stalk used in sorption of Fe(III) from synthetic solution

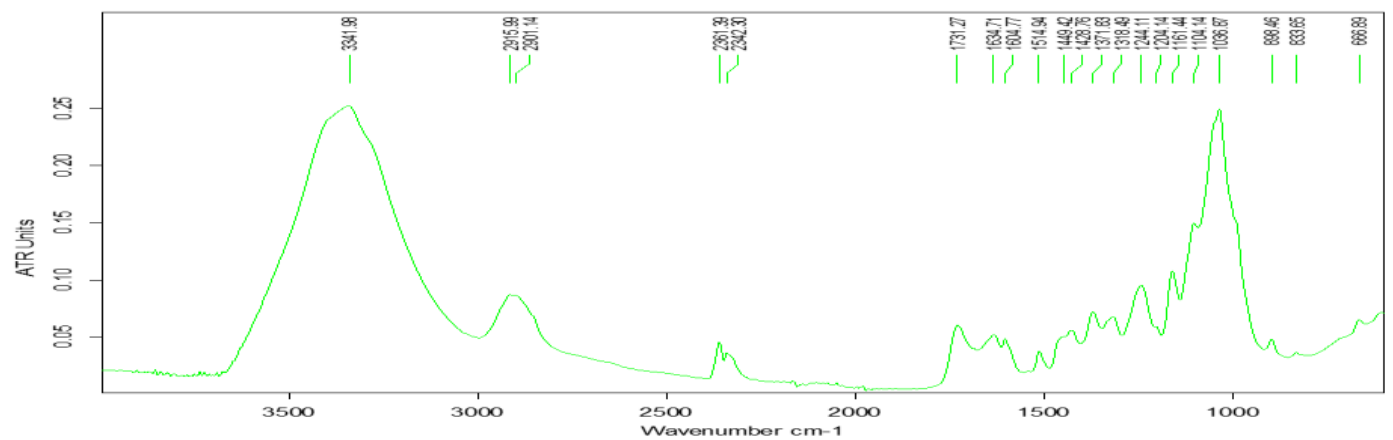

Figure 8. FTIR-ATR spectra of maize stalk used in sorption of $\mathrm{Cu}$ (II) from synthetic solution

\subsection{Thermal characterization of maize stalk}

The curves obtained from thermal analysis (TG) were recorded to determine temperatures values that induced weight loss. For this purpose, the thermogravimetric analysis was performed with STA 409 $\mathrm{PC}$ oven in temperature range $30-800^{\circ} \mathrm{C}$ with ramp heating to $5^{\circ} \mathrm{C} / \mathrm{min}$ during $120 \mathrm{~min}$ for the shredded activated maize stalk (Figure 9) as well as for the maize stalk loaded with metals from synthetic solution (Figures 10-11). All curves recorded have several regions with significant weight loss. In a first stage, the fastest weight loss can be attributed to the evaporation of the water existing in pores of the maize stalk. Cellulose, hemicellulose and lignin are major compounds of this plant material [27]. Second stages of weight loss between $200-400^{\circ} \mathrm{C}$ range can be assigned to pyrolysis of hemicellulose. Another weight loss was registered between $400-600^{\circ} \mathrm{C}$ and was attributed to decomposition of cellulose. The lignin pyrolysis can be highlighted in the finally stage of this study in $600-800^{\circ} \mathrm{C}$ range. The weight loss to $94.8 \%$ and $93.29 \%$ for the material loaded with $\mathrm{Cu}$ (II) and $\mathrm{Fe}$ (III) compared to the weight loss of the reference material up to $98.15 \%$ demonstrates the sorption of the metallic cations in the maize structure.

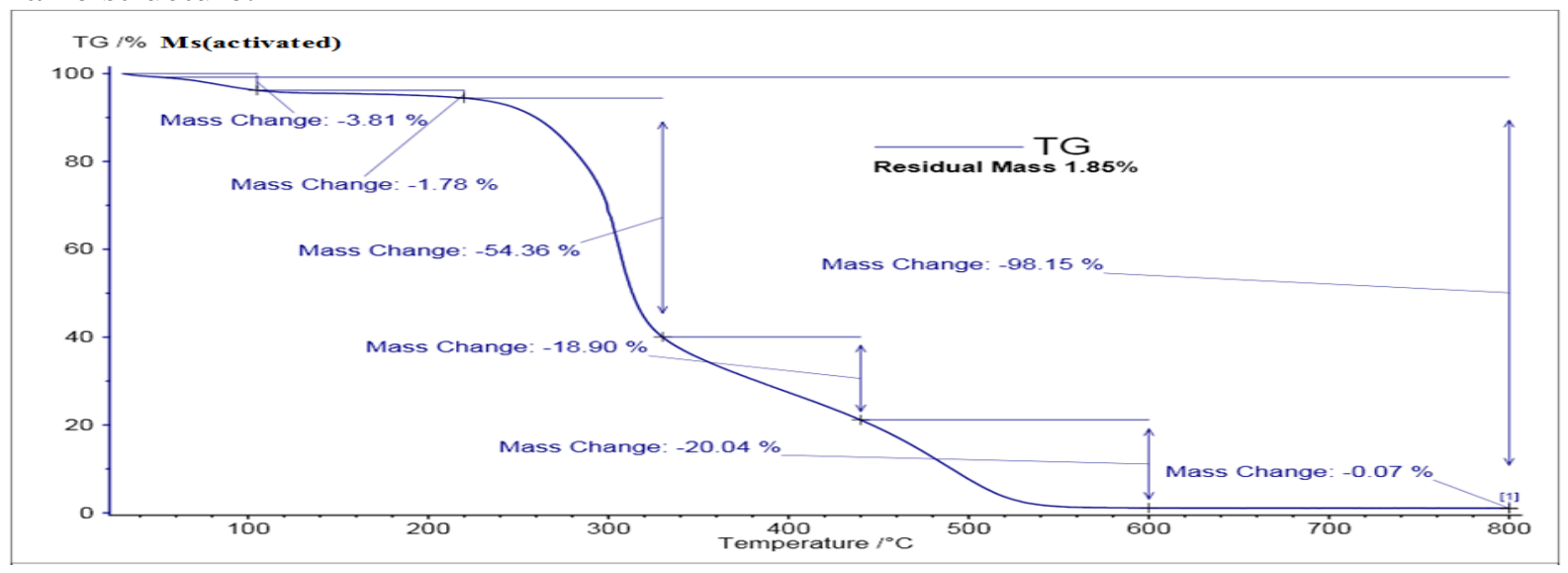

Figure 9. The effect of the thermal decomposition obtained for the activated maize stalk 


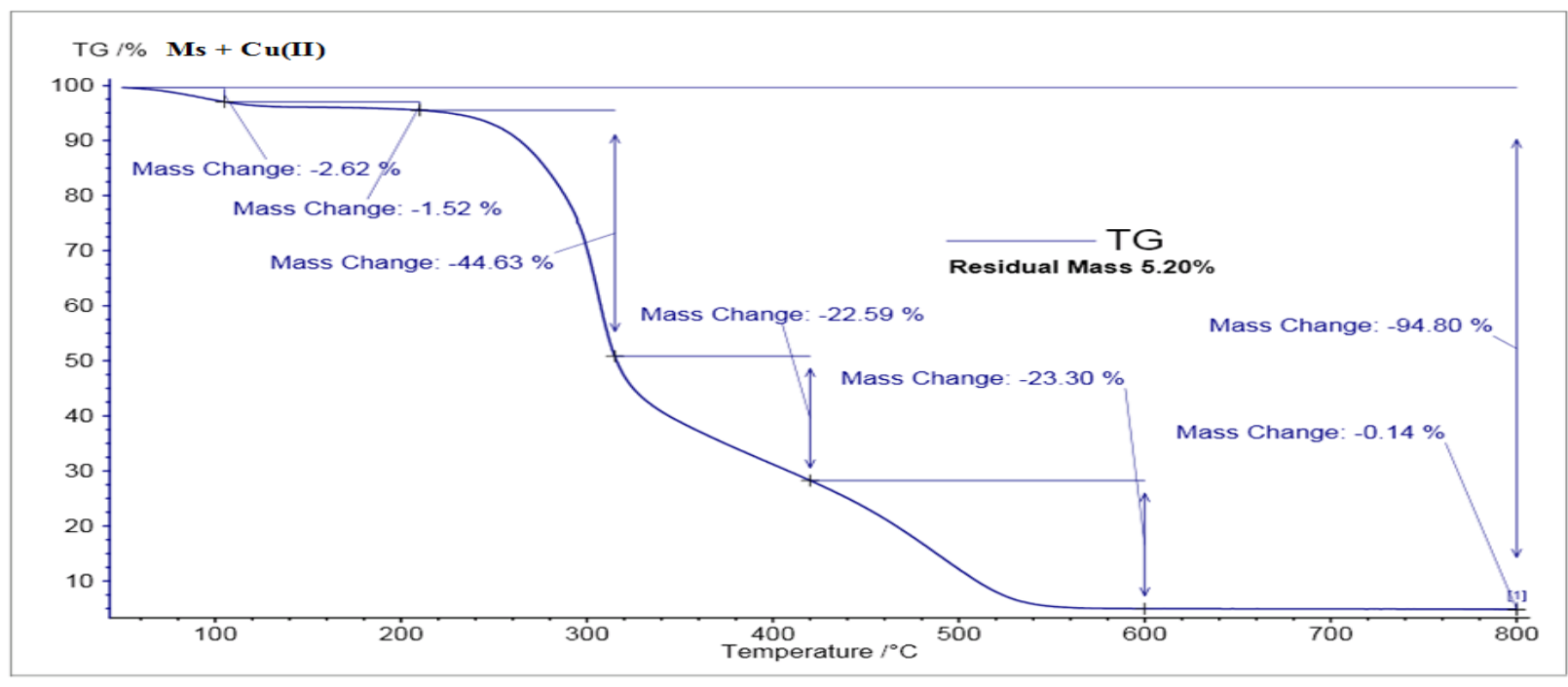

Figure 10. The effect of the thermal decomposition obtained for the $\mathrm{Ms}+\mathrm{Cu}(\mathrm{II})$

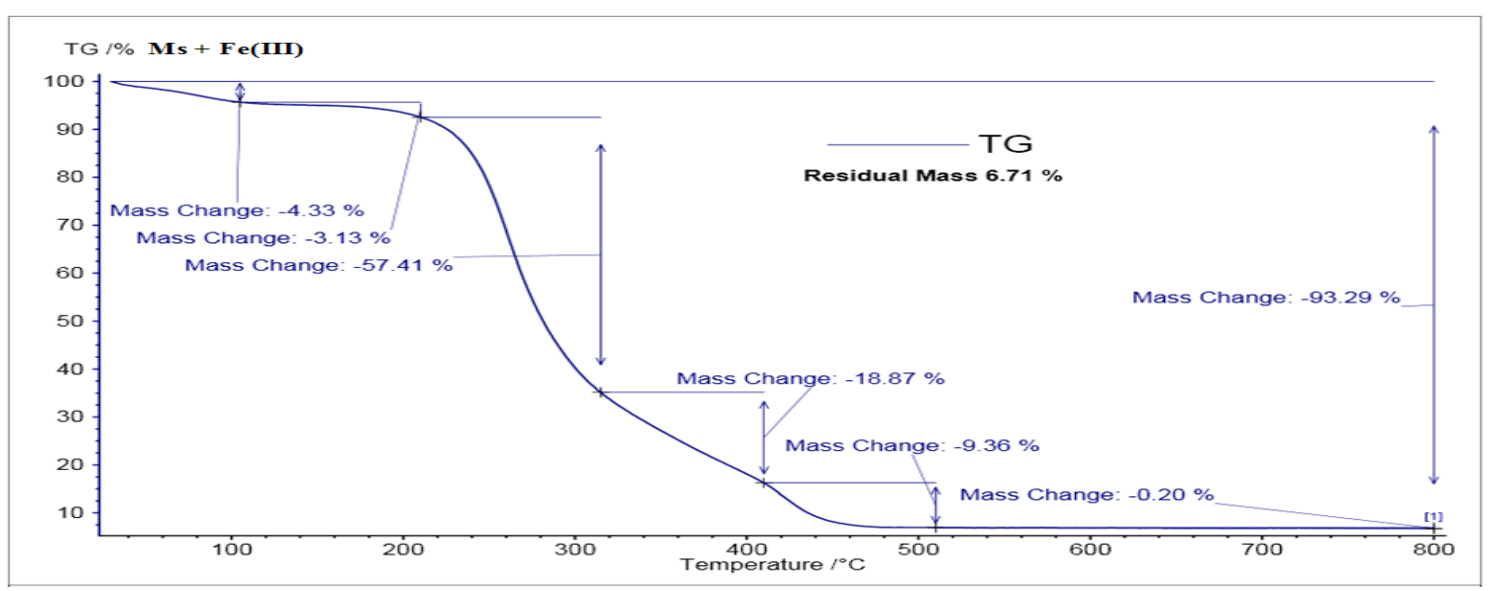

Figure 11. The effect of the thermal decomposition obtained for the the $\mathrm{Ms}+\mathrm{Fe}(\mathrm{III})$

\subsection{Maize stalk characterization by scanning electron microscopy (SEM)}

The activated maize stalk sieved under $1 \mathrm{~mm}$ was characterized using SEM analysis. Following the investigations, an elongated shape and porosity with irregular channels form were observed (Figures $12 \mathrm{a}-\mathrm{f}$ ). Also significant changes are observed for the material loaded with $\mathrm{Cu}(\mathrm{II})$ and $\mathrm{Fe}(\mathrm{III})$ compared to the blank biomaterial (Ms). In addition, the porous structure of the material allows to retain the metallic cations inside it [28, 29]. Moreover, for all material loaded with $\mathrm{Cu}$ (II) and $\mathrm{Fe}(\mathrm{III})$, globular images at the surface of the material were observed (Figures $12 \mathrm{a}-\mathrm{d}$ ), confirming the cations sorption.

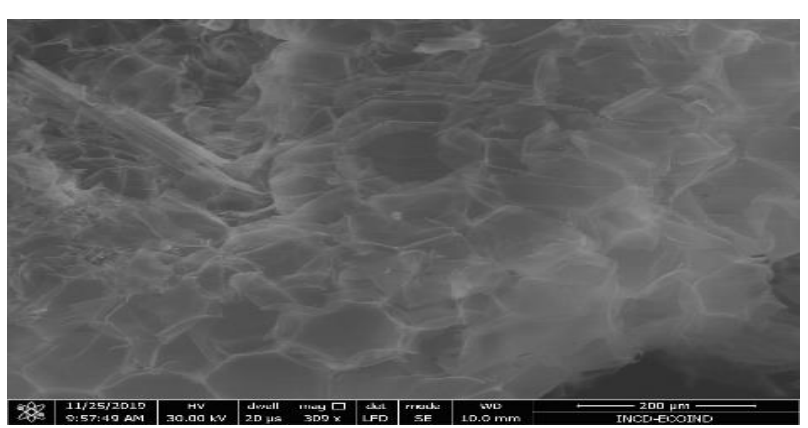

$\mathrm{M} \mathrm{s}+\mathrm{Cu}(\mathrm{II}) /(200 \mu \mathrm{m}),(\mathbf{a})$

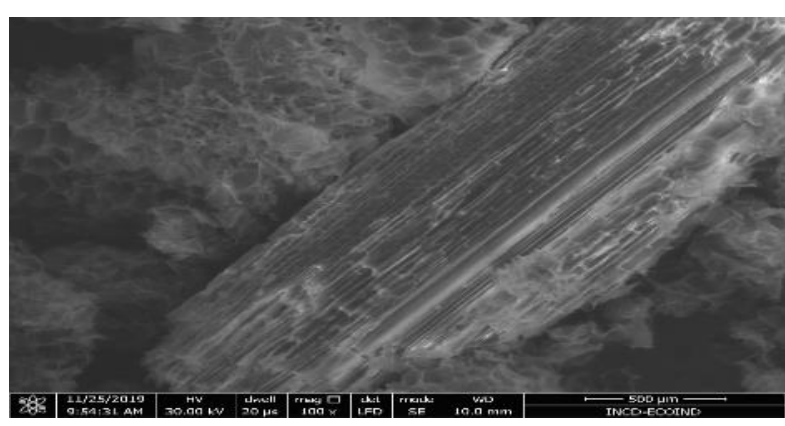

$\mathrm{M} \mathrm{s}+\mathrm{Cu}(\mathrm{II}) /(500 \mu \mathrm{m}),(\mathbf{b})$ 

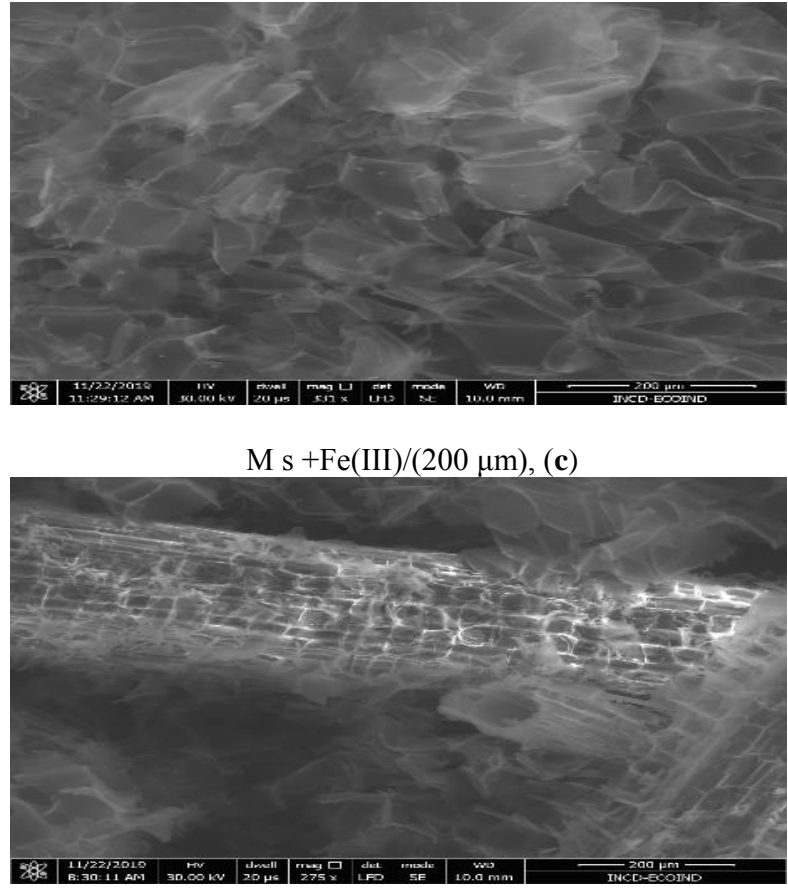

M s(activated)/(200 $\mu \mathrm{m}),(\mathbf{e})$

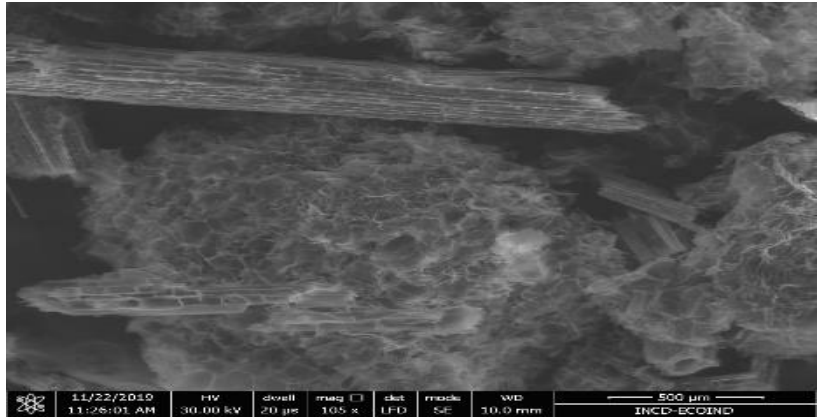

$\mathrm{M} \mathrm{s}+\mathrm{Fe}(\mathrm{III}) /(500 \mu \mathrm{m}),(\mathbf{d})$

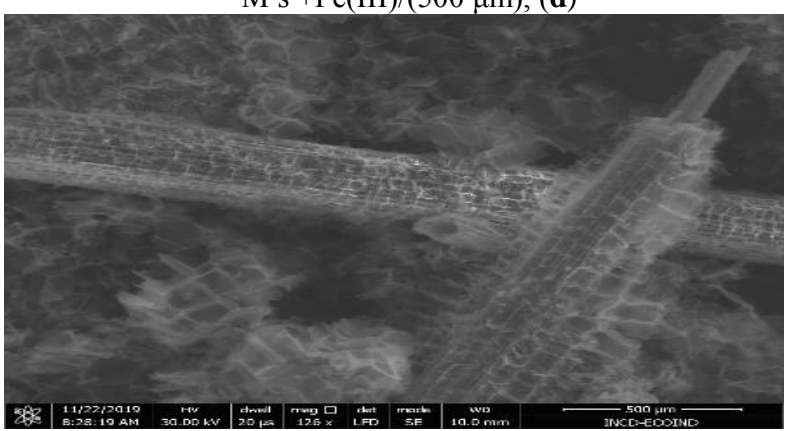

$\mathrm{M} \mathrm{s}($ activated $) / 500 \mu \mathrm{m},(\mathbf{f})$

Figure 12. Morphological characterization of maize stalk blank and samples loaded with metallic cations from synthetic solutions

\section{Conclusions}

A experimental model was implemented for $\mathrm{Cu}(\mathrm{II})$ and $\mathrm{Fe}(\mathrm{III})$ removal by new eco-friendly matrix with specific proprieties. The sorption of metallic cations from synthetic solutions can be performed with high efficiency in certain experimental conditions. During the sorption process the maximum capacity of the biomaterial was registered at $60 \mathrm{~min}$ in batch system. The role of the cation initial concentration on the maximum capacity of the maize stalk was also studied and showed that $0.1 \mathrm{~g}$ biomaterial assures removal efficencies of $53 \% \mathrm{Cu}(\mathrm{II})$ and $58 \% \mathrm{Fe}(\mathrm{III})$ at initial concentration of 0.4 $\mathrm{mg} / \mathrm{L}$. Experimental results releaved that maize stalk shoud be applied for selectively retains of some cations like $\mathrm{Cu}$ (II) and $\mathrm{Fe}$ (III) as a treatment method for various wastewater sources with heavy metal content. In addition when strongly acid solutions are used the whole quantity of metallic cation was recovered by successive cycles. Moreover, those efficient bio-recovery provides an attractive possibility to use those eco-friendly matrix instead of conventional synthetic materials.

Acknowledgments: The authors are grateful for the financial support received from the Ministry of Research and Innovation through Program Nucleu, contract no. 20N/2019, Project code PN 190403 01.

\section{References}

1. VASILE, G., MARIN, N.M., CRUCERU, L., SIMION, M., GALAON, T., LEHR, C.B., Determination of ultra-trace mercury in water samples based on cold vapor atomic fluorescence spectrometry using a gold trap, Rev. Chim., 67(8),2016, 1427-1432.

2. VASILE, G., MARIN, N.M., PETRE, J., CRUCERU, L., Ultrasonic nebuliser, a useful tool for improving the sensibility of trace element detection in surface water, J. Environ. Prot. Ecol., 17(1), 2016, 31-41.

3. NGUYEN, K.M., NGUYEN, B.Q., NGUYEN, H.T., NGUYEN, H.T., Adsorption of arsenic and heavy metals from solutions by unmodified iron-ore sludge, Appl. Sci., 9, 2019, 619.

4. DINU, C., UNGUREANU, E.M., VASILE, G., KIM, L., PASCU, L.F., SIMION, M., Evaluation of the bioavailability and pollution indexes of some toxic metals in polluted soils from an abandoned mining area, Rev. Chim., 69(11), 2018, 4141-4147. 
5. DINU, C., UNGUREANU, E.M., VASILE, G., KIM, L., IONESCU, I., ENE, C., SIMION, M., Soil and vegetation pollution from an abandoned mining area situated in Hunedoara County, Romania, Rev. Chim., 69(1), 2018, 14-20.

6. KIM, L., VASILE, G., STANESCU, B., CALINESCU, S., BATRINESCU, G., Distribution and bioavailability of mobile arsenic in sediments from a mining catchment area, J. Environ. Prot. Ecol., 16(4), 2015, 1307-1315.

7. NGUYEN, H.T., NGUYEN, B.Q., DUONG, T.T., BUI, A.T., NGUYEN, H.T., CAO, H.T., MAI, N.T., NGUYEN, K.M., PHAM, T.T., KIM, K.W., Pilot-Scale Removal of Arsenic and Heavy Metals from Mining Wastewater Using Adsorption Combined with Constructed Wetland, Minerals, 9, 2019, 379.

8. ZHENG, L., ZHU, C., DANG, Z., ZHANG, H., YI, X., LIU, C., Preparation of cellulose derived from corn stalk and its application for cadmium ion adsorption from aqueous solution, Carbohyd. Polym., 90, 2012, 1008-1015.

9. MAJID, R., The removal of Zinc, Chromium and Nickel from industrial waste water using Corn cobs, Iraqi J. Sci, 55(1), 2014, 123-131.

10. MUTHUSAMY, P., MURUGAN, S., SMITHA, M., Removal of nickel ion from industrial waste water using maize cob, Int J Biol Sci., 1(2), 2012, 7-11.

11. NOROZI, F., HAGHDOOST, G., Application of Corn Cob as a Natural Adsorbent for the Removal of Mn(VII) Ions from Aqueous Solutions, Orient J. Chem., 32(4), 2016, 2263-2268.

12. DANG, V., DOAN, H., DANG-VU, T., LOHI, A., Equilibrium and kinetics of biosorption of cadmium(II) and copper (II) ions by wheat straw, Bioresour. Technol., 100, 2009, 211-219.

13. DHIR, B., KUMAR, R., Adsorption of heavy metals by Salvinia biomass and agricultural residues, Int $J$ Environ Res., 4, 2010, 427-432.

14. FAROOQ, U., KHAN, M.A., ATHAR, M., KOZINSKI, J.A., Effect of modification of environmentally friendly biosorbent wheat (Triticum aestivum) on the biosorptive removal of cadmium(II) ions from aqueous solution, Chem Eng J, 171, 2011, 400-410.

15. FARAJZADEH, M.A., MONJI, A.B., Adsorption characteristics of wheat bran towards heavy metal cations, Sep Purif Technol., 38, 2004, 197-207.

16. PEHLIVAN, E., ALTUN, T., PARLAYICI, S., Utilization of barley straws as biosorbents for $\mathrm{Cu}^{2+}$ and $\mathrm{Pb}^{2+}$ ions, J Hazard Mater., 164, 2009, 982-986.

17. CALINESCU, O., MARIN, N.M., IONITA, D., PASCU, L.F., TUDORACHE, A., SURPATEANU, G., BADEA, I.A., ABOUL-ENEIN, H.Y., Selective removal of sulfate ion from different drinking waters, Environmental Nanotechnology, Monitoring \& Management, 6, 2016, 164-168.

18. ALNAJRANI, M.N., ALSAGER, O.A., Removal of Antibiotics from Water by polymer of intrinsic Microporosity: isotherms, Kinetics, thermodynamics, and Adsorption Mechanism, Sci. Rep., 10, 2020, 1-14.

19. ACHARY, P.G.R., GHOSH, M.R., MISHRA, S.P., Insights into the modeling and application of some low cost adsorbents towards Cr(VI) adsorption, Materials Today: Proceedings, 2020.

https://doi.org/10.1016/j.matpr.2020.01.433

20. MARIN, N.M., TIRON, O., PASCU, L.F., COSTACHE, M., NITA-LAZAR, M., BADEA, I.A., Synergistic methodology based on ion exchange and biodegradation mechanisms applied for metal complex dye removal from waste waters, Rev. Chim., 69(1), 2018, 38-44.

21. MARIN, N.M., PASCU, L.F., STANCUlESCU, I., IORDACHE, O., JIANU, D., PETRESCU, L., BADEA, I.A., Maize stalk as natural ion exchanger for hazardous pollutants, Rev. Chim., 68(8), 2017, 71-73.

22. LV, G., WU, S., Analytical pyrolysis studies of corn stalk and its three main components by TG-MS and PyGC/MS, J Anal Appl Pyrol., 97, 2012, 11-18.

23. HUANG, S., ZHOU, L., LI, M.C., WU, Q., ZHOU, D., Cellulose nanocrystals (CNCs) from corn stalk: Activation energy analysis, Materials, 10(1), 201, 80, https://doi.org/10.3390/ma10010080

24. ZHOU, X., WANG, M., FANG, S., LIU, X., LIU, P., Effect of Alkaline Black Liquor Recycling on Alkali Combined with Ozone Pretreatment of Corn Stalk, Molecules, 24, 2019, 2836.

25. GUO, L., ZHANG, B., BAI, S., MA, X., WANG, Z., Synthesis and application of functionalized ionic liquids as solvent to corn stalk for phenolic resin modification, E-Polymers, 15, 2015, 195-201, https://doi.org/10.1515/epoly-2014-0195 
26. MCCANN, M.C., DEFERNEZ, M., URBANOWICZ, B.R., TEWARI, J.C., LANGEWISCH, T., OLEK, A., WELLS, B., WILSON, R.H., CARPITA, N.C., Neural network analyses of infrared spectra for classifying cell wall architectures, Plant Physiol., 143(3), 2007, 1314-1326.

27. HUANG, S., WU, Q., ZHOU, D., HUANG, R., Thermal decomposition properties of materials from different parts of corn stalk, BioResources, 10(2), 2015, 2020-2031.

28. SONG, S.T., SAMAN, N., JOHARI, K., MAT, H., Removal of Hg(II) from aqueous solution by adsorption using raw and chemically modified rice straw as novel adsorbents, Ind Eng Chem Res, 52(36), 2013, 1309213101.

29. SUBAGYO, A., CHAFIDZ, A., Banana pseudo-stem fiber: Preparation, characteristics, and applications, in: Banana Nutrition-Function and Processing Kinetics, IntechOpen, 2018, https://doi.org/10.5772/intechopen.82204

$\overline{\text { Manuscript received: 09.03.2020 }}$ 